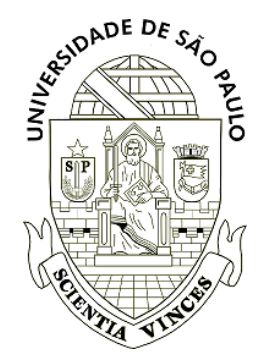

Universidade de São Paulo

Biblioteca Digital da Produção Intelectual - BDPI

Croton rufolepidotus (Euphorbiaceae s. str.), a New Species from Antioquia, Colombia

NOVON, v.20, n.3, p.248-251, 2010

http://producao.usp.br/handle/BDPI/15812

Downloaded from: Biblioteca Digital da Produção Intelectual - BDPI, Universidade de São Paulo 


\section{Croton rufolepidotus (Euphorbiaceae s. str.), a New Species from Antioquia, Colombia}

Author(s) :Maria Beatriz Rossi Caruzo, Ricarda Riina, Inês Cordeiro, and Paul E. Berry

Source: Novon: A Journal for Botanical Nomenclature, 20(3):248-251. 2010.

Published By: Missouri Botanical Garden

DOI:

URL: http://www.bioone.org/doi/full/10.3417/2008111

BioOne (www.bioone.org) is a a nonprofit, online aggregation of core research in the biological, ecological, and environmental sciences. BioOne provides a sustainable online platform for over 170 journals and books published by nonprofit societies, associations, museums, institutions, and presses.

Your use of this PDF, the BioOne Web site, and all posted and associated content indicates your acceptance of BioOne's Terms of Use, available at www.bioone.org/ page/terms_of use.

Usage of BioOne content is strictly limited to personal, educational, and noncommercial use. Commercial inquiries or rights and permissions requests should be directed to the individual publisher as copyright holder. 


\title{
Croton rufolepidotus (Euphorbiaceae s. str.), a New Species from Antioquia, Colombia
}

\author{
Maria Beatriz Rossi Caruzo, ${ }^{1,3}$ Ricarda Riina, ${ }^{2}$ Inês Cordeiro, ${ }^{3}$ and Paul E. Berry ${ }^{2}$ \\ ${ }^{1}$ Departamento de Botânica, Instituto de Biociências, Universidade de São Paulo, \\ Caixa Postal 11461, 05422-970, São Paulo, SP, Brazil. mbrcaruzo@hotmail.com \\ ${ }^{2}$ University of Michigan Herbarium and Department of Ecology and Evolutionary Biology, \\ 3600 Varsity Drive, Ann Arbor, Michigan 48109-2228, U.S.A. \\ ${ }^{3}$ Instituto de Botânica, Secretaria do Meio Ambiente, Caixa Postal 3005, 01061-970, \\ São Paulo, SP, Brazil
}

Abstract. Croton rufolepidotus Caruzo \& Riina (Euphorbiaceae s. str.), a new species from Colombia, is here described and illustrated. The new species is endemic to an area of lowland secondary forests in Antioquia. Morphological characters indicate that this species belongs to Croton sect. Cleodora (Klotzsch) Baill. due to its arborescent habit, petiolar glands, 15 to 25 stamens, as well as the pistillate flowers with imbricate sepals and multifid styles.

Key words: Colombia, Croton, Croton sect. Cleodora, Euphorbiaceae, IUCN Red List.

Croton L. is a pantropical genus with an estimated 1223 species in the Euphorbiaceae family (Govaerts et al., 2000). Although the genus occurs mostly in tropical regions worldwide, it also has some representatives in subtropical and northern temperate areas. In the Neotropics, its centers of diversity are Brazil, the West Indies, and Mexico (Burger \& Huft, 1995). In Colombia, there are 80 species of Croton (Murillo, 2004), including herbs, shrubs, and trees occurring in all kinds of habitats, with the greatest number of species concentrated in the Andean region of the country (Murillo, 1999). As a result of ongoing systematic studies on Croton sect. Cleodora (Klotzsch) Baill. by the senior author, new species have been described for that section (Caruzo et al., 2008, 2010). In this paper, we describe C. rufolepidotus Caruzo \& Riina, a new species of Croton sect. Cleodora known from Antioquia Department, Colombia, where it grows in lowland secondary forests.

Croton rufolepidotus Caruzo \& Riina, sp. nov. TYPE: Colombia. Antioquia: Tarazá, Corr. El 12, camino El 12-Barro Blanco, Km 4 NO Medellín, $210 \mathrm{~km}$ en troncal del Caribe, bht $/ \mathrm{bmht}, 7^{\circ} 30^{\prime} \mathrm{N}$, $75^{\circ} 16^{\prime}$ W, 25 July 1987, R. Callejas, J. Betancur \& F. J. Roldán 3611 (holotype, MO; isotypes, DAV, HUA, US). Figure 1.
Haec species Crotoni salutari Casar. affinis, sed ramulis cylindricis, stipulis auriculatis, inflorescentiae omnibus cymulis proximalibus pistillatis, bracteis linearibus, staminibus 15 ad 25, floribus femineis majoribus lobis calycis foliaceis non carnosis petalis reductis carentibus et stylis multifidis differt.

Tree 6-10 m tall, monoecious, indument rufoussilvery, lepidote trichomes without a central ray, trichomes pale, reddish, or sometimes with a reddish center and a pale margin; branchlets terete, rufoussilvery, covered by reddish and scattered pale trichomes. Leaves alternate; lamina 3-11.5 × $1-$ $4.5 \mathrm{~cm}$, narrowly ovate to ovate-elliptic, discolorous, apex narrowly acute to acuminate, base rounded to slightly cordate, margin entire, adaxial surface glabrous, abaxial surface densely lepidote, covered by pale trichomes and scattered reddish trichomes or trichomes with a reddish center and a pale margin, venation pinnate, brochidodromous, secondary veins 5 to 11 , abruptly upturned toward the next ones, tertiary veins inconspicuous; petiole $0.5-1.5 \mathrm{~cm}$, with a pair of stalked basilaminar glands ca. $1 \mathrm{~mm}$ diam., stalks $1-$ $1.5 \mathrm{~mm}$; stipules 0.5-1.5 cm, auriculate, apex caudate, deciduous. Inflorescence $2.5-6.5 \mathrm{~cm}$, terminal; inflorescence axis terete, striate, lepidote; proximal cymules pistillate, with a single flower, distal cymules staminate, with 1 or 2 flowers, bracts 3-5 mm, linear, prophylls inconspicuous. Staminate flowers ca. $1 \mathrm{~cm}$, campanulate, pedicels ca. $6 \mathrm{~mm}$; calyx ca. $4 \mathrm{~mm}$, lepidote externally, rufous-silvery, covered by reddish and scattered pale trichomes, glabrate internally; calyx lobes 5 , united up to half of their length, ca. $2 \mathrm{~mm}$, entire, equal, valvate, triangular, apex acute; petals ca. $4 \mathrm{~mm}$, spatulate, densely villous externally, apex with an uneven margin; disk 5-segmented; stamens 15 to 25, filaments subulate; receptacle villose with simple trichomes. Pistillate flowers $1-1.4 \mathrm{~cm}$, flask-shaped; pedicel 4-6 mm; calyx 6-8 mm, lepidote externally, rufous-silvery, covered by reddish and scattered 


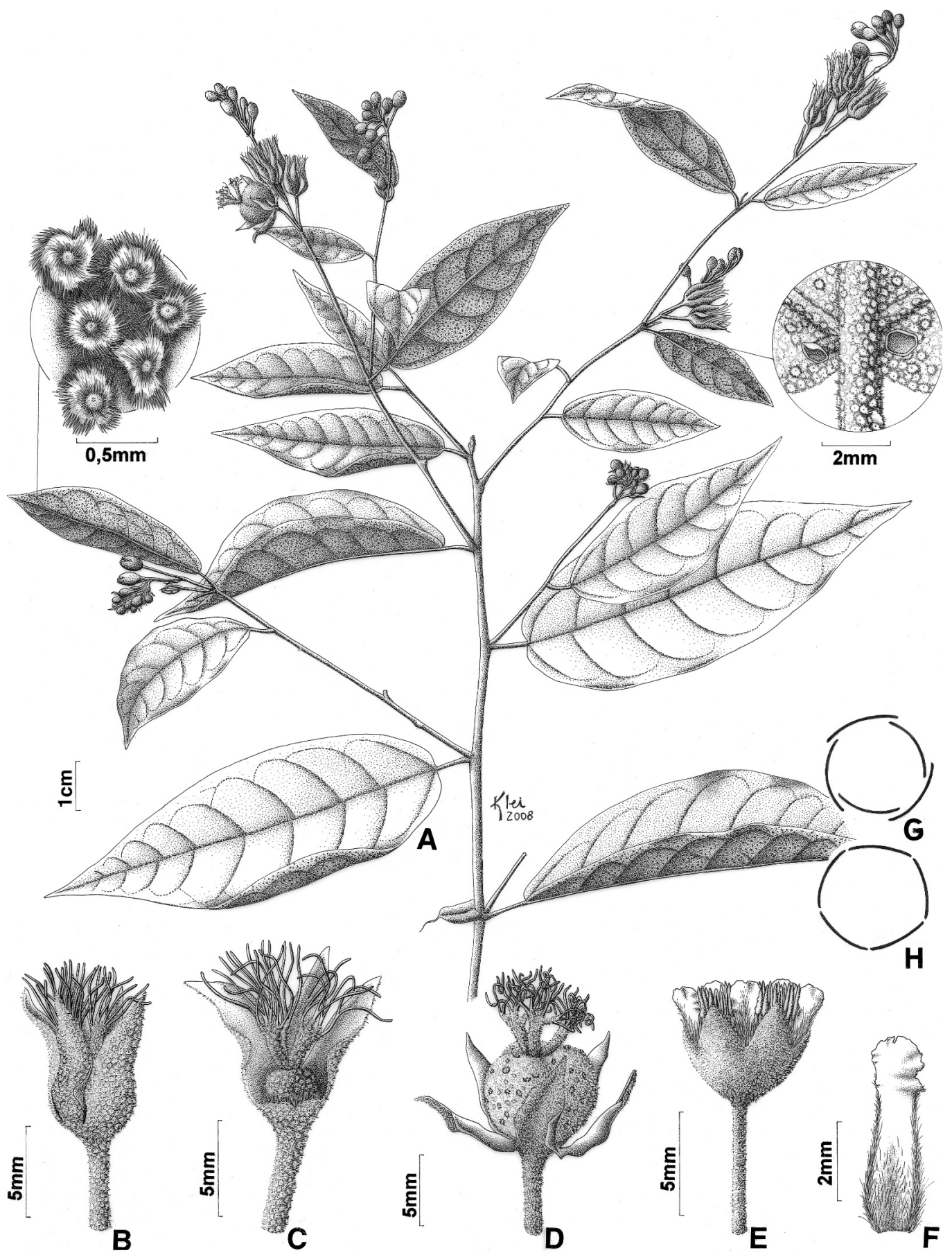

Figure 1. Croton rufolepidotus Caruzo \& Riina. - A. Branch with flowers and fruits. -B. Pistillate flower. -C. Detail of the gynoecium. - D. Fruit. - E. Staminate flower. —F. Petal of the staminate flower. —G. Aestivation of the pistillate sepals. -H. Aestivation of the staminate sepals. Drawn from the holotype Callejas et al. 3611 (MO).

pale trichomes, glabrate internally; calyx lobes 5 , united at the base, $6-8 \mathrm{~mm}$, equal, quincuncial, ovate-lanceolate, foliaceous, not fleshy; petals absent; disk entire, slightly 5-lobed; ovary sub- globose, lepidote; styles 3 , connate at the base, then divided into 3 short columns ca. 1/3-1/2 of the stylar length, each one branching into 8 terminal arms, with a total of 24 tips. Capsules ca. $1.5 \mathrm{~cm}$, 
Table 1. Principal characters distinguishing Croton rufolepidotus from C. salutaris.

\begin{tabular}{lll}
\hline \hline \multicolumn{1}{c}{ Character } & \multicolumn{1}{c}{ C. rufolepidotus } & \multicolumn{1}{c}{ C. salutaris } \\
\hline Trichomes & lepidote without a central ray & lepidote-porrect, with a long central ray \\
Branchlet shape & terete & angular \\
Stipule shape & auriculate & linear-lanceolate \\
Bract shape & linear & subulate \\
Proximal cymules of inflorescence & pistillate & pistillate and staminate \\
Stamen number & 15 to 25 & 15 \\
Pistillate flower length $(\mathrm{mm})$ & $10-14$ & $7-8$ \\
Pistillate calyx length $(\mathrm{mm})$ & $6-8$ & $3-4$ \\
Pistillate calyx lobes & not fleshy & fleshy \\
Reduced pistillate petals & absent & present \\
Pistillate sepals in fruit & slightly accrescent & not accrescent \\
Division of styles & multifid (more than 12 terminal tips) & quadrifid (12 terminal tips) \\
Habitat & lowland secondary forest & montane rainforest \\
Distribution & Antioquia, Colombia & southeastern Brazil \\
\hline
\end{tabular}

subglobose, 3-angled, lepidote, sepals slightly accrescent; seeds not seen.

Distribution and habitat. Croton rufolepidotus is endemic to Antioquia, Colombia, where it grows in lowland secondary forests, between 180 and $310 \mathrm{~m}$ elevation. According to R. Callejas (pers. comm.), much of the area where this species has been collected has since been deforested for coca plantations (Erythroxylum coca Lam. and E. novogranatense (D. Morris) Hieron.).

IUCN Red List category. Following IUCN Red List criteria (IUCN, 2001), Croton rufolepidotus can be considered as Critically Endangered (CR Blab) due to its restricted distribution (known from only one location) and the continuing decline of the area and quality of habitat where the species occurs.

Etymology. The specific epithet of this new species is taken from the Latin and refers to the rufous color of its lepidote indument.

Relationships. Following the sectional synopsis of Croton by Webster (1993), and based on current revisionary work and phylogenetic studies on Croton sect. Cleodora by the first author, the new species clearly belongs to this Neotropical section. The suite of characters shared by members of section Cleodora are the arborescent habit; the petiolar glands in an abaxial or lateral position; 15 to 25 stamens; quincuncial or imbricate, usually accrescent, and sometimes fused pistillate sepals; and quadrifid (12 terminal tips) or multifid (more than 12 terminal tips) styles fused at the base or into a longer column.

Among the other species within section Cleodora, this new species is morphologically most similar to Croton salutaris Casar. from the Atlantic rainforest of southeastern Brazil (São Paulo, Minas Gerais, Rio de Janeiro, and Espírito Santo states), but that species differs from $C$. rufolepidotus in several features, which are shown in Table 1 . The vegetative features that best distinguish $C$. salutaris from $C$. rufolepidotus are the stipule shape (linear-lanceolate in C. salutaris vs. auriculate in C. rufolepidotus) and branchlet morphology (angular in C. salutaris vs. terete in $C$. rufolepidotus).

Paratypes. COLOMBIA. Antioquia: Tarazá, Corr. El Doce, 210 km NNE of Medellín, carr. El Doce-Barro Blanco, near entrance to Hac. Las Mercedes, rd. outside of finca, $7^{\circ} 30^{\prime} \mathrm{N}, 75^{\circ} 16^{\prime} \mathrm{W}, 25$ July 1987, W. W. Thomas \& C. J. Castaño C. 5525 (COL, HUA, JAUM, MO, NY); Tarazá, Corr. El 12, Vía El Doce-Barro Blanco, Hac. las Mercedes, potrero San Juan, bht/bhmt, $7^{\circ} 30^{\prime} \mathrm{N}, 75^{\circ} 20^{\prime} \mathrm{W}, 7$ Nov. 1987, $R$. Callejas, F. J. Roldán, A. L. Arbeláez \& D. L. Echeverry 5425 (F, HUA).

Acknowledgments. Thanks are due to Klei Rodrigo Souza for the illustrations and to Conselho Nacional de Desenvolvimento Científico e Tecnológico $(\mathrm{CNPq})$, Brazil, for the fellowship awarded to the first author. We are also grateful to the herbaria COL, DAV, F, HUA, JAUM, MEDEL, MO, NY, and US for providing access to their collections. We thank Gordon McPherson and one anonymous reviewer for their comments and corrections.

\section{Literature Cited}

Burger, W. \& M. Huft. 1995. Flora costaricensis: Euphorbiaceae. Fieldiana, Bot. 36: 1-169.

Caruzo, M. B. R., R. Riina, I. Cordeiro \& P. E. Berry. 2008. Croton campanulatus (Euphorbiaceae s.s.), a new species from the Brazilian Atlantic rain forest. Brittonia 60(3): 261-264.

, I. Cordeiro, P. E. Berry \& R. Riina. 2010. A new species of Croton section Cleodora (Euphorbiaceae s.s.) from Minas Gerais, Brazil. Phytotaxa 3: 27-33. 
Govaerts, R., D. G. Frodin \& A. Radcliffe-Smith. 2000. World Checklist and Bibliography of Euphorbiaceae (and Pandaceae), 4 vols. Royal Botanic Gardens, Kew, Richmond.

IUCN. 2001. IUCN Red List Categories and Criteria, Version 3.1. Prepared by the IUCN Species Survival Commission. IUCN, Gland, Switzerland, and Cambridge, United Kingdom.
Murillo, J. 1999. Composición y distribución del género Croton (Euphorbiaceae) en Colombia, con cuatro especies nuevas. Caldasia 21(2): 141-166.

2004. Las Euphorbiaceae de Colombia. Biota Colomb. 5(2): 183-200.

Webster, G. L. 1993. A provisional synopsis of the sections of the genus Croton L. (Euphorbiaceae). Taxon 42: 793-823. 